\title{
SLOW TOURISM CONCEPT AND CULTURAL SITES: IS THE TOWN OF KOTOR (MONTENEGRO) READY FOR THE CITTASLOW MOVEMENT?
}

\author{
Iva Bulatović ${ }^{1}$ \\ Roberto Micera ${ }^{2}$ \\ 'University Mediterranean, \\ Montenegro \\ ${ }^{2}$ Institute for Research on Innovation and \\ Services for Development (IRISS), \\ Italy
}

\begin{abstract}
:
The purpose of this paper is to present the concept of slow tourism and the ways in which destinations can adopt slow tourism to ensure sustainable tourism development. Destinations of outstanding natural beauty and impressive cultural and historical heritage such as the Town of Kotor, in Montenegro, always attract a large number of tourists, but deal with sustainability issue. In this paper, tourism development in Kotor City is analyzed, as well. For the purpose of this paper empirical research methods are used. Key Informant Interviews have been implemented. Results show that the Town of Kotor needs immediate action and developing slow tourism appears as the most suitable option. However, according to key informants' opinion there is a long road to success and all elements of tourist system must be included. The paper is a good scientific base for further research and idea elaboration. For the first time the concept of slow tourism is investigated in the context of Montenegrin destinations which represents the special contribution of the paper.
\end{abstract}

Keywords:

Cittaslow, Tourism, Culture, Kotor, Montenegro

\section{INTRODUCTION}

Culture, as one of the most important tourist attractor (Correia et al., 2013) has always been the sustainability issue. Do we use all cultural resources in tourism and how do we do that? In suitable way or unsustainable? Culture tourism is defined as a special interest tourism. The main reasons for travelling and visiting cultural cities are learning, cultural tours, special cultural events, sightseeing (UNWTO, 2018). The main tourist activities are: visiting museums, galleries, sculptures, castles, archaeological and historical cites, theatre, attending art festivals, sightseeing (McKercher et al., 2002). According to the UNWTO cultural tourism is the pillar of the tourist consumption. It accounts over 39\% of tourist arrivals (Richards, 2018). Cultural cites protected by the UNESCO and listed in the World Heritage Cites list are attracting millions tourists (Santa-Cruz and Lopez-Guzman,2017). Developing tourism in protected areas is a great challenge for destination management. How to ensure sustainability it depends on tourist policy. Destinations need to define proper strategy based on sustainable development pillars. In this paper, we are going to present the concept of slow tourism as a sustainable alternative for cultural destinations.
Correspondence:

Iva Bulatović

e-mail:

iva.bulatovic@unimediteran.net 
The paper includes five sections. Firstly, we are going to define slow tourism and explain the Cittaslow movement in short. In the second, we are going to present Kotor City as tourist destination. Then, methodology and sample will be presented. Results are given in the fourth section and in the last, but not least section discussion and main conclusions are considered.

\section{LITERATURE REVIEW}

Slow tourism has been created as a response to mass tourism. Actually, slow tourism means avoidance of fast and mass tourism (Moore, 2012). Slow tourism represents the modern concept of tourist development based on culture, nature, relaxation and human energy refreshment. The most appropriate definition of slow travel is given by Lumsdon and McGrath (2011,p.274): "Slow travel is a holistic approach in that the outward journey, destination and return are integral; they make one travel experience. For most of the experts, there is no division between slow travel as the journey and slow tourism as a way of enjoying the destination. They are one and the same." Yurtseven and Kaya (2011) treat slow tourism as special interest tourism, as specific type of tourism and emphasize that slow tourism practice is well known and it is not something new, but for the first time slow tourism practice tried to be standardized. On the other side, slow tourism means destination discovery in depth, tourists' long stay at destination, avoiding commercial products and services (Guiver, McGrath, 2016).

In addition, slow tourism is strictly sustainable tourism (Di-Clemente et al., 2015). As Fullagar et al. (2012, p.19) stated "slow travelers are often distinguished by a desire to experience a different temporality to that of the 'bucket list' of places to stop over and move on from". Slow tourists are looking for peaceful, nature-based destinations. They want to be educated about culture and history of destination, to interact with locals, to try authentic food and bevarege. They usually do not buy food in stores but from local producers, buy self-catering accommodation, participate in traditional and folklore events etc. (Heitmann et al., 2011). Oh et al. (2014) treated slow tourism as "Goal-Driven Consumption". It means that slow tourists are motivated by particular, individual, personal goals and they strive to achieve these goals. Additionally, slow tourism includes pro environmental behavior of tourists and low-impact tourist activities such as cycling, hike and bike, sightseeing, flora nad fauna watching etc. Special focus is on the transport modes which should be sustainable (Conway, Timms, 2012).

The forerunner of Slow tourism is the idea of wellness developed by doctor Dunn in 1959 (Weiermair, Mathies, 2004). Today, slow tourism is not just related to the wellness concept and wellness movement, but to the Slow food and Slow city (Cittaslow) movements (Robinson, Heitmann, Dieke, 2011). Actually, Slow tourism is a result of Slow food and Slow City movements (Ritzer, 1996; Petrini, 2001). According to Nilsson et al. (2011) Slow food and Slow city don't include tourism development, but destinations, that are transformed into Slow cites, are very attractive to tourists. Cittaslow (Slow City) movement was established in Italy in 1999. Cities: Greve-in-Chianti, Bra, Positiano and Orvieto were the first "Slow cities" in the world (Radstrom, 2014). Cittaslow concept has been adopted by 236 cites in 30 countries up to date (Cittaslow, 2018). Cittaslow founded as a result of globalisation, mass production and mass tourism (Nilsson, et al., 2011). Cittaslow association is a network of small cities ( up to 50000 citizens) which implemented special set of standard in order to ensure destination sustainability (Presenza et al., 2015).

Cittaslow standard includes 72 requirements grouped in 7 categories: Energy and Environment Policy, Infrustructure Policy, Quality of urban life policy, Agricultural, Tourist and Artisan Policies, Policies For Hospitality, Awareness And Training, Social Cohesion and Partnerships. Environmental requirements seem to be the most important (Cittaslow,2018). In spite of the fact that Cittaslow movement is based on the number of visitors reduction, this movement is synonym for organized, well planned tourism development in smaller destinations - tourist destinations known by their cultural and historical heritage.

\section{TOURISM IN THE TOWN OF KOTOR (MONTENEGRO)}

Kotor (Montenegrin: Kotor, Italian: Cattaro, Albanian: Kotorri) is a city, Town and port in the Montenegrin coast in the far north-eastern part of the Boka Kotorska Bay, one of the most beautiful bays in the Mediterranean. Kotor (Area: $355 \mathrm{~km}^{2}$ ) with its impressive cultural and historical heritage attracts tourists from 
all over the world. According to the latest official census of the population in 2011, Kotor Town had 22,634 citizens, distributed in 56 settlements (MONSTAT, 2018). The Town of Kotor has diverse and significant resources and potentials for economic, tourism and cultural development (Radovic, 2010).

The most important tourist cite in the Town of Kotor is The Old Town $\left(146 \mathrm{~km}^{2}\right)$. The Old Town of Kotor is surrounded by solid ramparts, built in the time of the Byzantines, the dynasty of Nemanjić and The Venetians. The ramparts are high $20 \mathrm{~m}$ and wide up to 10 meters. The town is characterized by numerous features of a typical Mediterranean settlement: larger and smaller squares and narrow and curved streets. The largest square is the Square of the Arms.

There are numerous old buildings in the town: the Renaissance Prince's Palace, a baroque clock tower from the 17th century, the Grgurin Palace where Is now Maritime Museum, the Cathedral / Basilica of Saint Tryphon, built in 1166, the church of St. Luke of 1195, the church of St. Mary (Blessed Ozana), renovated in 1221, the church of St. Paul from 1266, the church of St. Klara, with a Franciscan monastery, where a library of about 20,000 books and 50 incunabula, the oldest printed books until 1500. The palaces in Kotor are: Buža (XIV century), Drago (XV), Pima (XVI), Vrakjen (XVIII) and Grubonja (XVII century) (Kordić, 2009; Kalezić, 1970).

The Old Town of Kotor is unique example of fortification architecture in Europe and it is under UNESCO's protection from 1979 (UNESCO, 2018). The Town of Kotor is a summer destination. Despite the National and local management's efforts to extent tourist season, Kotor is not very attractive to tourists during winter months. In addition to sightseeing of the old town and cultural and historical sights, other tourist activities are: sport and recreation, diving, sailing, walking, hiking, biking.

Cultural tourism development in the Town of Kotor has been on the increase in the last 6 year. More specifically, the number of tourists' arrivals increased by $117.93 \%$ in 2017 compared to 2011 . The number of tourist overnight stays increased by 63.15\%. The share of tourist traffic in the Town of Kotor in Montenegrin tourism was 3.77\% in 2011, but 5.64\% in 2017 (MONSTAT, 2018). The Town of Kotor has 3 hotels, 3 garni hotels, 14 small hotels, 3 boutique hotels, 2 campsites and 6 hostels. The Town accounts more than 4500 private accommodation units (MONSTAT, 2018). The great number of accommodation units goes to private rooms. This can be judged by tourist professionals and academic experts because it is not in correlation with the National Tourist Policy. Actually, The Strategy of Tourism Development in Montenegro until 2020 ( Ministry of sustainable development and tourism, 2008) identifies the area of the Town of Kotor as a luxurious destination. In real world, there is not a lots of new small luxurious hotels, but the number of hostels and private accommodation is increasing. There are over 55 restaurants, taverns, pizzerias. The two traditional manifestations that are held in Kotor are: Kotor Art and Boka's night. These events are organizing in the summer peak season. Eight receptive tourist agencies operate in the Town of Kotor (Tourist Organization of Kotor, 2018). In recent years, more and more cruisers have sailed into the port of Kotor. MSC, TUI, Princes Cruises, Celebrity Cruises, Prestige Cruise Services LLC and many others are cruiser companies that usually sail into Kotor's port ( Tourist Organization of Kotor, 2018). It means that the Old Town is more visited by tourists. The number of cruisers which sail into the port of Kotor has been increased by $50 \%$ in 2016 (480) compared to 2011(319). During the 2017 Kotor has been visited by 540000 cruiser's passengers or $188.74 \%$ more than in 2011. Cruising tourism in the Town of Kotor has been increasing at great scale. So many tourists visit at the same time the Old Town of Kotor. It can be very worrying for cultural tourism sustainability and for further generations.

Montengro pretends to be sustainable tourism destination, but it doesn't look like that the real situation correlates with its pretensions. The Old Town of Kotor is overcrowded during summer season. Environmetal impacts and social-cultural impacts has never been measured. Carrying capacity level and visitors monitoring haven't been established. Sustainable destination management is under question and the assumptions of the authors are that the urgent interventions are needed. In the era of extremely intensive tourist growth, the Cittaslow concept seems to be the right solution especially for cultural cites. Developed tourist destinations have already recognized the importance of ensuring sustainability and have applied new concepts which work. In that regards, readiness of the Town of Kotor for adopting Cittaslow standard is investigated through deep interview with key informants - experts from Montenegrin tourist sector. Methodology, sample and results are presented in the text bellow. 


\section{METHODOLOGY AND SAMPLE}

For the purpose of the paper the empirical research methods are used. The Town of Kotor was examined as tourist destination using quantitative and qualitative analysis. Furthermore, key informant interview was used for analyzing possibilities of the destination to adopt Cittaslow standard. Interview was done during the summer 2018.

Interview questionnaire contained 20 open structured questions. Interview was prepared and implemented by telephone to 5 key informants (tourism professionals -key informants 1 and 2, academic and business sector - key informants 3 and 4, representative of the local management - key informant 5). Key informant interview questionnaires were filled by 4 male and 1 female. The average age of key informants is 41.3 of key informants has $\mathrm{PhD}$ degree, and 2 has MSc degree in social sciences (geography, tourism management, economics). 4 key informants come from the Town of Kotor. It must be noted that more than 15 key informants were contacted but they didn't want to give answers in spite of the fact the interview is anonymous due to privacy issues.

Furthermore, the special checklist was created in order to evaluate the importance of Cittaslow standard adoption and to analyze the actual situation in the Town of Kotor. Checklist was defined according to Cittaslow standard (benchmarking assessment). Likert's scale, from 1 to 5 (1- not important/unsatisfactory situation; 5 -very important/very satisfactory situation) is used. Checklist was distributed to key informants by e-mail. Based on mean values calculation, the authors designed Radar Chart.

\section{RESULTS}

\section{Is the Town of Kotor ready for Cittaslow movement?}

Key informants' interview answers

Key informant 1: The most developed tourist products in the Town of Kotor are: culture tourism, cruising tourism and excursions. Tourists from cruisers "block" the Old Town during the cruise season. You can't pass through, but they don't spent money there. Sightseeing is their main activity. That is not profitable for destination, especially not for the Old Town of Kotor. It is better not to comment destination management. I can define a lots of disadvantages, but I think the most dangerous one lies in the lack of knowledge. Maybe the actual integration in the EU will change situation, but I am not optimistic. The Town of Kotor is not that I knew as a child. I grew up there and I am very sad, but must be realistic - the Old Town of Kotor loses its spirit. I am not very familiar with the Cittaslow Movement. In Italy it works, but here, we don't have capacity for adopting it. Destination is ready for sure, but there is not responsible sustainable destination management and we can't expect that Cittaslow movement becomes reality in the Town of Kotor.

Key informant 2: It is evident that the cruising tourism is in expansion. A lots of visitors. Yes, I said visitors, not tourists. They don't stay in the Old Town of Kotor. They come, pass and leave. Achieving tourism sustainability is the most difficult task for all of us. Firstly, it is important to educate and organize destination management. There is no place for political issues. We have to protect our "pearl" and Kotor it is. It jeopardizes the dangers of delineation from the UNESCO list which would be catastrophic for Montenegro and especially for tourism. Adoption of Cittaslow standard is the best solution for the Town of Kotor, but it is not possible for now. Why? Because, the all system must be reorganized and I can't say that the top management is interested in applying Cittaslow standard.

Key Informant 3: I will be short. Destination ( The Town of Kotor) has prospered on the basis of cultural treasures. If we are not urgently taking corrective actions in accordance with the principles of sustainability, we can forget tourism in the Town of Kotor. On the other hand, there is also a local population that is under siege by tourists during the season. Mass tourism must be a past. Slow tourism can bring numerous benefits to Kotor, it is only necessary to work more intensively on promoting slow tourism. And whether destination management is willing to give up financial benefits of cruisers, this is an interesting question to which no one has an answer. 
Key Informant 4: The Old Town is the most attractive tourist destination on the Montenegrin coast. Everyone wants to visit the Old Town Kotor. It can be treated as a serious pressure on the environment. I am not sure that our system can deal with this challenge, especially during the tourist season. Slow tourism is the good solution for future tourism development in the Town of Kotor. Significant improvements are needed at all levels. I will not criticize the top destination management. We are all guilty of the current situation. The Old Town is overcrowded during summer season. Locals have stopped going to the old city. The Town of Kotor is a port city, we shouldn't forget it. More than $70 \%$ of locals has benefits of tourism. Financial of course, but we don't think too much about negative impacts of tourism. We are not aware of the fact that space is suffering of rapidly tourism development. I think, according to the destination lifecycle, now is the right time for radical changes. Transfer from mass to slow and sustainable tourism is "must to do". Sustainability must be our common goal. Local Authority is not able to deal wit it alone. We can't see that local management is working on it. Maybe, the initiative must go from the top - Government of Montenegro, or from bottom. If I can say, the bottom initiative must be very strong, a little bit aggressive and persistent. I am skeptical about both approaches. I believe in new generations, their skills and knowledge and of course in their entrepreneurial souls. Kotor is our cultural treasure, the most beautiful place on this shore of Adriatic. It would be shame to destroy the most valuable resource. I really like your idea about Cittaslow standard adoption. It is great. I hope that will not be placed just in papers. I would be glad to see the results of your work in practice.

Key informant 5: The Town of Kotor is becoming more popular in tourism context. There are a plenty of tourist attractors, but the most important and the most significant part of our tourist offer is the Old Town. We are proud of tourism development results. Kotor has more accommodation facilities and more tourists. I can't say that tourism can endanger destination. On the contrary, it has more positive effects than negative. We need to pay attention on both, but there is no risk for sustainability. Our policy is well structured and you can see that we have taken care on details. In addition, it is very difficult to implement all strategies in short period, but we hope in a long term we will achieve all goals related to the sustainability. Developing slow tourism in the Town of Kotor is a good vision, but not for now. If we start developing slow tourism, we will lose important market segments such as cruising tours. Cruisers full the local and the state budget, we must keep that market.

\section{Key informants' benchmark assessment}

In this section, the Town of Kotor is analized according to Cittaslow standard presented in the Cittaslow Charter (2017) by key imformants. As it was stated before, the importance of standard adoption and actual situation in the Town of Kotor are evaluated by Likert's scale, from 1 to 5 (1- not important/unsatisfactory situation; 5-very important/very satisfactory situation). Based on average grades, Radar Chart shows research results. Key informants' benchmark assessment Key informants assessed that establishing environmental policy is the requirement of the highest importance. Environmental pollution could be the most dangerous issue for the Town of Kotor and for the Boka Kotorska Bay in general. High concentration of tourists at the same place could damage cultural heritage and affect local community. On the other side, water pollution is present due to frequently cruisers sails. It is well known that ports are polluted destinations. Noise pollution is also present, but the local management and inspection system are trying to minimize it by the music limitation regulations. Construction is booming industry and sustainable infrastructure policies are urgent needs. There is not visitor monitoring system, the telecommuting development is an average, promotion of social infrastructure, green urban areas are minimal etc. It means that quality of urban life policies are unsatisfactory. The same situation is in the case of agricultural, touristic and artisan policies. Human resources are well trained, professional and kind, but neither human resources in tourism nor citizens are not informed about Cittaslow movement. Awareness of sustainability and environment protection is at very low level. The best rated segment is social cohesion. Without joint cooperation any success in the sense of sustainability couldn't be expected. According to key informants opinion strong sustainable development initiatives are missing, as well. 


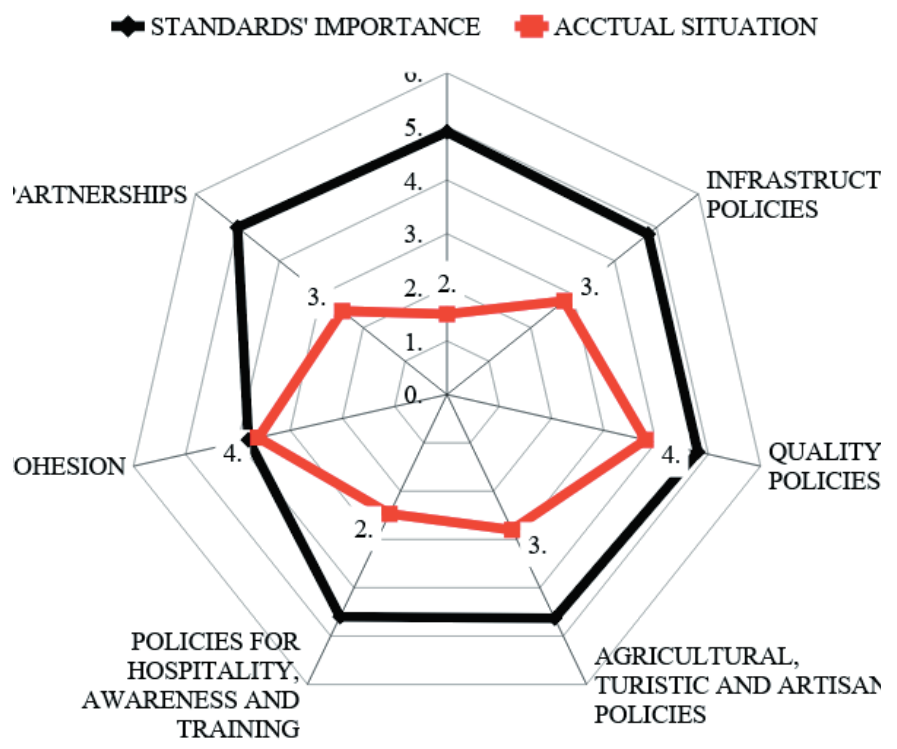

\section{DISCUSSION AND CONCLUSION}

Slow tourism is a good chance for all types of destinations that are dealing with sustainability issues, especially for cultural tourist cites. Accepting criteria for developing slow tourism is less attractive for destinations' economy, but in long term it is the only right strategy and could be very profitable especially for destinations based on cultural and historical heritage. Slow tourism requires strategic destination planning, strong organization and control mechanisms. As it was stated before, the number of tourists, tourists' overnight stays, cruisers' passengers who are interested in cultural tourism is increasing continuously. Tourist infrastructure expands, economic tourist impacts become stronger and stronger. It doesn't mean that tourism in the Town of Kotor is sustainable. The Town of Kotor is large enough to be able to implement Cittaslow standard. However, our analysis has shown that the gap between the Cittaslow standard and the current situation is huge. It is very difficult to expect from the local government to stop developing cruising tourism. However, traffic of passengers must be under urgent regulation. The Old Town is in the greatest danger. As a cultural property under the protection of UNESCO, it is not acceptable to circulate a large number of tourists throughout the summer season. The ecological impacts of tourism are not measured. Theoretical implications of the research: The paper represents a first step for further development of slow tourism concept and its standard specially designed for cities along the coast of Adriatic sea. Practical implications of the research: Cittaslow standard adoption can be an expensive project for the Town of Kotor, but the financial possibilities are numerous. With the use of European funds, the cittaslow concept could be established in Montenegro and neighboring countries. The paper is a basis for further project idea development. Authors' recommendation to other researchers, and above all to the destination management, is that it is the right time to achieve a significant competitive advantage on the cultural tourism market with the help of sustainable initiatives. At pratical level if policy makers and destination mangers of Kotor wants to ensure sustainability, then it should react immediately. It can be concluded that the Town of Kotor need new approach towards sustainability. Adoption of Cittaslow standard is a just one solution, but in general, developing of slow tourism is the only a good one future projection. Additionally, transforming current cultural tourism development into sustainable tourism is the most challenging task for all interested parts. Destination management must to change the vision, tourism policy, as well. The Cittaslow movement is not known among Montenegrin tourist experts and its promotion is needed. Stakeholders must be educated and prepared for changes, locals must support slow tourism developing. It would be a very long process, but not impossible. Joint efforts are needed. Just a small step forward is a big one. For instance, calculating carrying capacity, the visitor management would be a good strategy. It could be start point. As similar 
destinations (236 of them) have managed to adopt the Cittaslow standard, we believe that Kotor can do it, as well. Finally, the Town of Kotor is now attractive to tourists. However, if The Old Town of Kotor is removed from the list of world cultural heritage, this will significantly damage the development of tourism in Kotor, as well as the image of Montenegro as a tourist destination.

\section{REFERENCES}

Conway, D., \& Timms, B. F. (2012). Are slow travel and slow tourism misfits, compadres or different genres? Tourism Recreation Research, 37(1), 71-76. DOI:10.1080/02508281.2012.11081689

Correia, A., Kozak, M., \& Ferradeira, J. (2013). From tourist motivations to tourist satisfaction. International Journal of Culture, Tourism and Hospitality Research, 7(4), 411-424. DOI:10.1108/IJCTHR-05-2012-0022

Di-Clemente, E., Hernández-Mogollón, J. M., De Salvo, P., \& Campón-Cerro, A. M. (2015). Slow tourism: an alternative model for local and tourist development. Sustainable Tourism: A Collection of Tools and Best Practices, 23, 1-15.

Fullagar, S., Markwell, K., \& Wilson, E. (2012). Slow tourism: Experiences and mobilities. Bristol: Channel View Publications. Guiver, J. W., \& McGrath, P. (2016). Slow tourism: Exploring the discourses. Dos Algarves, 27, 11-34. DOI:10.18089/DAMeJ.2016.27.1

Heitmann, S., Robinson, P., \& Povey, G. (2011). Slow food, slow cities and slow tourism. Research themes for tourism, 114-127.

Kalezić, D. (1970). Kotor. Zagreb: Grafički zavod Hrvatske.

Kordić, S. (2009). Kotor- Vodič kroz grad. Kotor: Dobro more.

Lumsdon, L.M. \& McGrath, P. (2011). Developing a Conceptual Framework for Slow Travel: A Grounded Theory Approach. Journal of Sustainable Tourism, 19(3): 265-279. DOI:10.1080/09669582.2010.519438

McKercher, B., McKercher, R., \& Du Cros, H. (2002). Cultural tourism: The partnership between tourism and cultural heritage management. London: Routledge.

Moore, K. (2012). On the Periphery of Pleasure: Hedonics, Eudaimonics, and Slow Travel. Slow Tourism: Experiences and Mobilities, 54, 25.

Nilsson, J. H., Svärd, A. C., Widarsson, A., \& Wirell, T. (2007). Slow destination marketing in small Italian towns. Paper presented at the 16th Nordic Symposium in tourism and hospitality research, Helsingborg.

Oh, H., Assaf, A. G., \& Baloglu, S. (2016). Motivations and goals of slow tourism. Journal of Travel Research, 55(2), 205-219. DOI:10.1177/0047287514546228

Petrini, C. (2001). Slow food: The case for taste. New York: Columbia University Press.

Presenza, A., Abbate, T., \& Micera, R. (2015). The Cittaslow movement: opportunities and challenges for the governance of tourism destinations. Tourism Planning \& Development, 12(4), 479-488. DOI:10.1080/21568316. 2015.1037929

Radovic, M. (2010). Turisticka geografija Crne Gore. Bar: Fakultet za turizam, hotelijerstvo i trgovinu.

Radstrom, S. (2014). A PlaceSustaining framework for local urban identity: An introduction and history of Cittaslow. Italian Journal of Planning Practice, 1(1), 90-113.

Richards, G. (2018). Cultural tourism: A review of recent research and trends. Journal of Hospitality and Tourism Management, 36, 12-21 DOI:10.1016/j.jhtm.2018.03.005

Ritzer, G. (1996). The McDonaldization of society: An investigation into the changing character of contemporary society (Rev. ed.). Thousand Oaks, CA: Pine Forge Press.

Robinson, P., Heitmann, S., \& Dieke, P. (2011). Research themes for tourism. Wallingford, Oxfordshire: CABI. DOI:10.1079/9781845936846.0000

Santa-Cruz, F. G., \& López-Guzmán, T. (2017). Culture, tourism and World Heritage Sites. Tourism Management Perspectives, 24, 111-116. DOI:10.1016/j.tmp.2017.08.004

Weiermair, K., \& Mathies, C. (2004). The tourism and leisure industry: Shaping the future. Binghamton: Haworth Hospitality Press.

Yurtseven, H. R., \& Kaya, O. (2011). Slow tourists: A comparative research based on Cittaslow principles. American International Journal of Contemporary Research, 1(2), 91-98.

www.cittaslow.org

https://whc.unesco.org/en/list/125

www.monstat.me

http://www2.unwto.org/

http://www.tokotor.me/

http://www.mrt.gov.me/ministarstvo 